\title{
在宅脊能邀摥者の食生活満足度に関連する 食物找取状況・行動・食環境の要因
}

\author{
秦 希久子*1，稲山 貴代*1 \\ *1首都大学東京大学院人間健康科学研究科
}

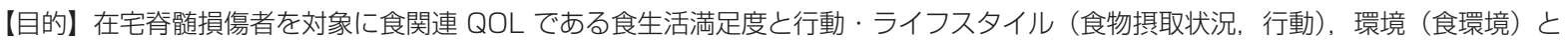
の関係を明らかにすることを目的とした。

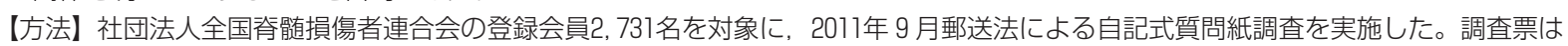
QOL（食関連 QOL)，食物摂取状況，行動，食環境を含む 8 つの概念で構成した。回答が得られた1，000名（回収率37\%）のうち853名 を解析対象とした（有効回答率 $31 \%$ )。従属变数は食関連 QOL である「食生活満足度」とし, 独立变数を「食物摄取状況」「行動」, 「食環境」として二項ロジスティック回帰分析にて単变量解析と多变量解析を行った。

【結果】多变量解析で食生活満足度と関連がみられたものは, 食物摃取状況では「緑黄色野菜」と「いも類」, 行動では「自分の健康の ために栄養や食事に気をつけているか」、「家族や仲間と食事や料理，栄養の事を話すか」「「健康診断受診有無」，食環境では「健康づ くりに家族や周囲の人は協力的か」,「食生活について一緒に考える仲間の有無」「「よく利用する食料品店や外食店で栄養バランスの良 い食品やメニューを得ているか」であった。

【結論】在宅脊髄損傷者の食生活満足度に関連する行動・ライフスタイル（食物摄取状況，行動）と環境（食環境）は, 副菜, 積極的 な自己管理，家族や仲間との会話，他者との関わり，食物へのアクセスであった。
\end{abstract}

栄養学雑誌, Vol.71 No.3 138-144 (2013)

キーワード：在宅脊骵損傷者，食生活満足度，食物摂取状況，行動，食環境

\section{I. 緒言}

世界保健機関のヘルスプロモーションのためのオタワ 憲章（1986）では, 人々が健康に到達する過程として 「個人や集団が望みを確認, 実現し，ニーズを満たし，環 境を改善し, 環境に対処すること」と, ヘルスプロモー ションと環境との関わりをとりあげている ${ }^{1)}$ 。健康日本 21 (第 2 次 $)^{2)}$ は，国民の生活の質 (Quality of Life，以下 QOL）の向上および社会環境の質の向上を図ることを目 的としており, 栄養・食生活では食生活, 食環境の双方 の改善を推進する観点から目標が設定されている。食を 通じた社会参加の機会の増加や健康のための資源へのア クセスの改善と公平性の確保は, 食に関する QOL および 環境の質の向上, ひいては健常者, 障がい者をわけるこ となく国民の健康寿命の延伸・健康格差の縮小につなが る。

健康日本 21 栄養・食生活の目標設定の理論枠組み ${ }^{3)}$ で用いられたプリシード・プロシードモデル ${ }^{4)}$ は, 包括 的なモニタリングシステムの形式となっており, 構成概 念の関連性やつながりを重視している。最終的な目標を QOL として「健康」,「行動・ライフスタイル」,「環境」 の要因が直接関係することが示されているが, 食を QOL
の観点から捉え他の食生活要因との関連を明らかにした 報告は少なく ${ }^{5)}$, さらに障がい者を対象とした研究はみら れない。障がい者の食に関する QOL に関連する要因を明 らかにすることにより，食生活の構成要因の関係性の確 認ができ，課題の整理や検討につながる。

著者らは，在宅で生活している脊髄損傷者（以下，在 宅脊損者）を対象に,プリシード・プロシードモデルを 応用した武見の理論枠組み ${ }^{6)}$ (以下, 理論枠組み) に基づ く調査票を用いて, QOL と健康を保つための栄養・食生 活支援に必要な基礎資料となる食生活の包括的特性につ いて報告している ${ }^{7)}$ 。在宅脊損者では健常者の食生活 ${ }^{8)}$ と違いがみられないこと, 女性や高齢者の食生活が良好 であること,リハビリテーションなどで重要視される損 傷部位による違いはほとんどみられないことを明らかに したが, 食生活の要因間の関係をみるには至っていない。 理論枠組み ${ }^{6)}$ の最終目標となる QOL と，それを説明す る食生活要因との関係を明らかにすることは，栄養・食 生活支援の方向性を示唆するものと考える。

そこで本研究では, 前報 ${ }^{7)}$ の調査デー夕を使用し, 在 宅脊損者を対象として, 食関連 QOLである食生活満足度 と行動ライフスタイル（食物摂取状況，行動)，環境（食 環境）との関係を明らかにすることを目的とした。 


\section{II. 方 法}

\section{1. 対象者ならびに手順}

本研究では前報「在宅脊䯣損傷者の食生活の包括的特 性ならびに性・年齢区分・損傷部位による差異について

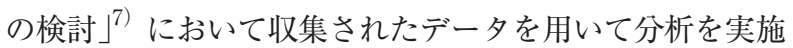
した。

対象は在宅で生活している脊髄損傷者とし, 脊䯣損傷 者（以下, 脊損者）が関わる全国組織として, 社団法人 全国脊髄損傷者連合会（以下，全脊連）会員に調查を依 頼し，郵送による質問紙調査を実施した。調查手順は前 報7)による。

質問紙調查票は, 理論枠組み ${ }^{6}$ にもとづき QOL（健康 度自己評価, 食関連 QOL), 健康状態, 食物摄取状況,

行動 (食行動・健康行動), 食行動の中間要因（食生活の 行動変容段階), 準備要因 (結果期待, セルフ・エフィカ シー, 食知識, 食態度, 食スキル), 属性, 食環境で構成 されており, 内容的妥当性抒よび表面的妥当性について 確認している。

登録会員のうち2,731名を調查対象とし, 調查票の回答 が得られた1, 000名（回収率37％）のうち，性，年齢，障 がい名, 損傷部位, QOL の項目が未記入の者, 施設入所 者の計147名を除外した853名（男性723名，女性130名） を解析対象者とした（有効回答率 $31 \%$ ）。なお，実施にあ たっては公立大学法人首都大学東京の研究倫理安全委員 会の審議, 承認を得た（承認番号23-18）。

\section{2. 調査項目と解析方法}

解析に用いた変数として, 従属変数は食を QOL の観点 から捉えた食関連 QOL として「食生活満足度」を採用し た。食生活満足度は, あなたは現在の食生活に満足して いますかとたずね，「とてもしている」「まあまあしてい る」「あまりしていない」「全然していない」の中から 1 つ選択してもらった。独立変数は, 行動・ライフスタイ ルにあたる「食物摂取状況」10項目と「行動（食行動・ 健康行動)」13項目, 環境にあたる「食環境」4 項目とし た。採用理由は, 理論枠組み ${ }^{6)}$ のベースとなっているプ リシード・プロシードモデル ${ }^{4)}$ において，QOL の向上に つながるものとしてあげられていることによる。

いずれの変数も分布を考慮し，肯定的な回答を 1 ，それ 以外の回答を 0 とした。食生活満足度と属性はクロス集 計表を作成し, $\chi^{2}$ 検定を行った。その後, 二項ロジス ティック回帰分析にて単変量と多変量解析を実施した。 単変量解析では, 1 つ 1 つ変数を投入し, 多変量解析で は，「食物摂取状況」をモデル1，「行動」をモデル 2， 「食環境」をモデル 3 とし，それぞれの変数を同時に投入
した。なお，共変量として性別，年齢，損傷部位，受傷 後経過年数, 居住形態, 社会参加の有無を投入し, ス テップワイズ法を用いた。

統計解析ソフトは IBM SPSS Statistics 19 （日本アイ・ ビー・エム株式会社）を用い，有意水準は両側検定で $5 \%$ とした。

\section{III. 結 果}

解析対象者は, 年齢の平均（標準偏差）は男性61.8 （11.3）歳, 女性57.9（13.7）歳, 受傷後経過年数の平均 は男性27.5（12.9）年, 女性27.1（15.3）年であった。 その他の属性の分布を表 1 に示す。

食生活満足度の人数分布は「とてもしている」「まあま あしている」「あまりしていない」「全然していない」そ れぞれ206名 (24\%)，535名 (63\%)，95名（11\%），17 名（2％）であった。食生活満足度を「とてもしている」 と「それ以外」でみると性，年齢区分，居住形態，社会 参加の有無で有意差がみられた。

食生活满足度と食物摂取状況, 行動（食行動・健康行 動), 食環境に関する項目との関倸について, 二項ロジス ティック回帰分析の結果を表 2 に示した。その結果，単 変量解析で最もオッズ比が高かったのは「健康づくりに 家族や周囲の人は協力的か」であり，家族や周囲の人が いつも協力的であると答えた在宅脊損者はそれ以外の回 答をした者より食生活に満足していた。次にオッズ比が 高かったのは「家族や仲間と食事や料理，栄養の事を話 すか」であり，いつも/時々話をしている者はそれ以外 の者より食生活に満足していた。次いで「自分の健康の ために栄養や食事について気をつけているか」,「食生活 について一緒に考える仲間の有無」の順にオッズ比が高 かった。

多変量解析に扔いて，モデル1で関連がみられた変数 は「緑黄色野菜（オッズ比 $(\mathrm{OR}): 2.07,95 \%$ 信頼区間 (CI) : 1.39-3.10)」, 「いも類 (OR: 1.56, CI: $1.07-$ 2.36)」であった。その他の食物は食生活満足度と関連が みられなかった。

モデル 2 では「自分の健康のために栄養や食事につい て気をつけているか (OR: 2. 55, CI: 1.68-3.80)」,「家 族や仲間と食事や料理，栄養の事を話すか (OR: 2. 05, CI: $1.32-3.18$ ) 」, 「健康診断受診の有無（OR: 1. 50, CI: 1.01-2.21)」が関連した。朝食摂取頻度や共食, 排 便の変数では関連がみられなかった。

モデル 3 では「健康づくりに家族や周囲の人は協力的 か (OR: 4. 97, CI: 3.20-7.72)」,「食生活について一緒 
表 1 食生活満足度と対象者の属性

\begin{tabular}{|c|c|c|c|c|c|c|c|c|c|}
\hline \multirow{3}{*}{ 項 } & \multirow{3}{*}{ 目 } & \multicolumn{8}{|c|}{ 食生活満足度 } \\
\hline & & \multicolumn{2}{|c|}{ 全 体 $^{\dagger}$} & \multicolumn{2}{|c|}{$\begin{array}{c}\text { とても満足している } \\
n=206\end{array}$} & \multicolumn{2}{|c|}{$\begin{array}{c}\text { それ以外 } \\
n=647\end{array}$} & \multirow[t]{2}{*}{$\chi^{2}$} & \multirow[t]{2}{*}{$p$} \\
\hline & & 人 & $(\%)$ & 人 & $(\%)$ & 人 & $(\%)$ & & \\
\hline \multirow[t]{2}{*}{ 性別 } & 男性 & 723 & (84.8) & 191 & $(92.7)$ & 532 & $(82.2)$ & 13.3 & $<0.001$ \\
\hline & 女性 & 130 & $(15.2)$ & 15 & $(7.3)$ & 115 & $(17.8)$ & & \\
\hline \multirow[t]{4}{*}{ 年齢区分 } & 49歳以下 & 146 & $(17.1)$ & 38 & $(18.4)$ & 108 & $(16.7)$ & 10.8 & 0.013 \\
\hline & 50～59歳 & 181 & $(21.2)$ & 29 & (14.1) & 152 & $(23.5)$ & & \\
\hline & $60 \sim 69$ 歳 & 309 & $(36.2)$ & 74 & $(35.9)$ & 235 & $(36.3)$ & & \\
\hline & 70歳以上 & 217 & $(25.4)$ & 65 & $(31.6)$ & 152 & $(23.5)$ & & \\
\hline \multirow[t]{3}{*}{ 損傷部位 } & 頸髄 & 247 & $(29.0)$ & 52 & $(25.2)$ & 195 & $(30.1)$ & 1.8 & 0.40 \\
\hline & 胸髄 & 438 & $(51.3)$ & 111 & $(53.9)$ & 327 & $(50.5)$ & & \\
\hline & 腰髄 & 168 & (19.7) & 43 & $(20.9)$ & 125 & (19.3) & & \\
\hline \multirow[t]{5}{*}{ 受傷後経過年数 } & 9 年以下 & 79 & $(9.7)$ & 19 & $(9.7)$ & 60 & $(9.8)$ & 2.9 & 0.58 \\
\hline & 10～19年 & 165 & $(20.3)$ & 43 & $(21.9)$ & 122 & (19.8) & & \\
\hline & 20～29年 & 179 & $(22.1)$ & 39 & (19.9) & 140 & $(22.8)$ & & \\
\hline & 30～39年 & 216 & $(26.6)$ & 47 & $(24.0)$ & 169 & $(27.5)$ & & \\
\hline & 40年以上 & 172 & $(21.2)$ & 48 & $(24.5)$ & 124 & $(20.2)$ & & \\
\hline \multirow[t]{2}{*}{ 居住形態 } & 一人暮らし & 106 & (12.4) & 11 & $(5.3)$ & 95 & (14.7) & 12.5 & $<0.001$ \\
\hline & 同居 & 747 & $(87.6)$ & 195 & $(94.7)$ & 552 & $(85.3)$ & & \\
\hline \multirow[t]{2}{*}{ 社会参加有無 } & あり & 543 & $(68.7)$ & 145 & $(75.1)$ & 398 & $(66.7)$ & 4.9 & 0.016 \\
\hline & なし & 247 & (31. 3) & 48 & $(24.9)$ & 199 & (33. 3) & & \\
\hline
\end{tabular}

† 未回答は欠損値として扱い, 除外した。

に考える仲間の有無（OR: 1.75, CI: 1.18-2.61)」,「よ く利用する食料品店や外食店で栄養バランスの良い食品 やメニューを得ているか (OR: 1.55, CI: 1.05-2.30)」 に関連がみられた。情報へのアクセスである「よく利用 する食料品店や飲食店から健康的な食事に関する情報を 得ているか」は関連がみられなかった。

\section{N. 考察}

理論枠組み ${ }^{6)} に$ 基づき, 在宅脊損者を対象に食関連 QOL である食生活満足度と行動・ライフスタイル, 環境 との関倸を検討した。関連した変数を要約すると, 食物 摂取状況は「副菜」, 行動（食行動・健康行動）は「積極 的な自己管理」,「家族や仲間との会話」, 食環境は「他者 との関わり」,「食物へのアクセス」であった。身体障が い者の食生活満足度と食生活の要因との関係を明らかに した研究は国内のみならず，国外でもこれまでに報告さ れておらず新しい知見であり, 今後の当該分野の健康教 育の企画や支援計画作成の有用な資料になると考元る。

食物摂取状況（モデル1) では, 食生活満足度と副菜 摄取に関連がみられた。脊損者は生活習慣病のリスクが
高く ${ }^{9)}, \mathrm{QOL}$ や健康を保つ上でも二次障害の予防は重要 である。例えば，肥満は身体障がい者にとって単に肥っ ていて動きにくいというだけではなく，すでにある障が いと組み合わさることによりその人の身体活動，社会的 なイベントや地域活動への参加を制限し ${ }^{10)}$ ，車椅子やそ の他の補助装置を使ったとしても移動をより困難なもの にし，最終的には QOL を低下させることになる ${ }^{11)}$ 。野菜 や果物の摂取量の増加は体重コントロールに重要な役割 があり ${ }^{12)}$, 循環器疾患, 2 型糖尿病の一次予防に効果が あることから ${ }^{13,14)}$ ，健康日本21（第2 次）の栄養・食生 活の目標設定 ${ }^{2)}$ では野菜摂取量の増加に注目している。 このことから, 健康づくりのための方策として, 在宅脊 損者においても副菜摂取が目標として設定されることの 妥当性を支持するものと考える。

行動（モデル 2 ）では, 健康診断受診の有無が関連し た。疾病リスクが高くなる脊損者は，定期的な健康診断 や人間ドックの受診が针められる ${ }^{15)}$ 。しかし，本調查対 象者の受診率は $57 \%$ であり, 特定健診の目標受診率 $70 \%{ }^{16)}$ と比べ低い。受診率が高くならない理由として, 脊損者は排泄機能障害や裖瘡の治療のためにかかりつけ の病院が決まっている事が多く, 改めて健康診断を受け 
表 2 食生活満足度と食物摂取状況，行動，食環境の関係（二項ロジスティック回帰分析）

\begin{tabular}{|c|c|c|c|c|c|c|c|c|}
\hline & \multirow[b]{2}{*}{ 変 } & \multirow[b]{2}{*}{ 回 答 肢 } & \multicolumn{4}{|c|}{ 食生活満足度 ${ }^{\dagger}$} & \multirow{2}{*}{$\frac{\text { 単変量解析 }^{\ddagger}}{\mathrm{OR}(95 \% \mathrm{CI})^{\S}}$} & \multirow{2}{*}{$\frac{\text { 多変量解析 }^{\dagger}}{\text { OR }(95 \% \mathrm{CI})^{\S}}$} \\
\hline & & & \multicolumn{2}{|c|}{ とても満足 } & $\begin{array}{l}\text { それ上 } \\
\text { 人 }\end{array}$ & $\begin{array}{l}\text { 以外 } \\
(\%)\end{array}$ & & \\
\hline & ごはん & $\begin{array}{l}\text { 日に } 2 \text { 食以上 } \\
\text { それ以外 }\end{array}$ & $\begin{array}{r}158 \\
48\end{array}$ & $\begin{array}{l}(77) \\
(23)\end{array}$ & $\begin{array}{l}440 \\
207\end{array}$ & $\begin{array}{l}(68) \\
(32)\end{array}$ & - & - \\
\hline & 肉 & $\begin{array}{l}\text { ほぼ毎日／週に4,5 回 } \\
\text { それ以外 }\end{array}$ & $\begin{array}{r}43 \\
163\end{array}$ & $\begin{array}{l}(21) \\
(79)\end{array}$ & $\begin{array}{l}146 \\
499\end{array}$ & $\begin{array}{l}(23) \\
(77)\end{array}$ & - & - \\
\hline & 魚 & $\begin{array}{l}\text { ほぼ毎日／週に4,5 回 } \\
\text { それ以外 }\end{array}$ & $\begin{array}{r}86 \\
120\end{array}$ & $\begin{array}{l}(42) \\
(58)\end{array}$ & $\begin{array}{l}211 \\
433\end{array}$ & $\begin{array}{l}(33) \\
(67)\end{array}$ & $\begin{array}{c}1.49(1.05-2.12)^{*} \\
1\end{array}$ & - \\
\hline $\begin{array}{l}\text { 食 } \\
\text { 物 } \\
\text { 摂 }\end{array}$ & 卵 & $\begin{array}{l}\text { ほぼ毎日／週に4,5 回 } \\
\text { それ以外 }\end{array}$ & $\begin{array}{r}78 \\
126\end{array}$ & $\begin{array}{l}(38) \\
(62)\end{array}$ & $\begin{array}{l}204 \\
432\end{array}$ & $\begin{array}{l}(32) \\
(68)\end{array}$ & - & - \\
\hline 取 & 大豆・大豆製品 & $\begin{array}{l}\text { ほぼ毎日／週に4,5 回 } \\
\text { それ以外 }\end{array}$ & $\begin{array}{r}110 \\
96\end{array}$ & $\begin{array}{l}(53) \\
(47)\end{array}$ & $\begin{array}{l}298 \\
349\end{array}$ & $\begin{array}{l}(46) \\
(54)\end{array}$ & - & - \\
\hline 㿝 & 牛乳·乳製品 & $\begin{array}{l}\text { ほぼ毎日／週に4, } 5 \text { 回 } \\
\text { それ以外 }\end{array}$ & $\begin{array}{r}131 \\
75\end{array}$ & $\begin{array}{l}(64) \\
(36)\end{array}$ & $\begin{array}{l}359 \\
283\end{array}$ & $\begin{array}{l}(56) \\
(44)\end{array}$ & $\begin{array}{c}1.55(1.09-2.20) * \\
1\end{array}$ & - \\
\hline $\begin{array}{l}\text { ル } \\
1\end{array}$ & 緑黄色野菜 & $\begin{array}{l}\text { 日に } 1 \text { 食以上 } \\
\text { それ以外 }\end{array}$ & $\begin{array}{r}159 \\
47\end{array}$ & $\begin{array}{l}(77) \\
(23)\end{array}$ & $\begin{array}{l}390 \\
253\end{array}$ & $\begin{array}{l}(61) \\
(39)\end{array}$ & $\begin{array}{c}2.16(1.46-3.18)^{* * * *} \\
1\end{array}$ & $2.07(1.39-3.10)^{* * *}$ \\
\hline & その他の野菜 & $\begin{array}{l}\text { 日に } 1 \text { 食以上 } \\
\text { それ以外 }\end{array}$ & $\begin{array}{r}159 \\
45\end{array}$ & $\begin{array}{l}(78) \\
(22)\end{array}$ & $\begin{array}{l}411 \\
236\end{array}$ & $\begin{array}{l}(64) \\
(36)\end{array}$ & $\begin{array}{c}2.04(1.38-3.04)^{* * * *} \\
1\end{array}$ & - \\
\hline & いも類 & $\begin{array}{l}\text { ほぼ毎日／週に4,5 回 } \\
\text { それ以外 }\end{array}$ & $\begin{array}{r}63 \\
142\end{array}$ & $\begin{array}{l}(31) \\
(69)\end{array}$ & $\begin{array}{l}125 \\
519\end{array}$ & $\begin{array}{l}(19) \\
(81)\end{array}$ & $\begin{array}{c}1.84(1.25-2.70)^{* *} \\
1\end{array}$ & $\begin{array}{c}1.56(1.07-2.36)^{*} \\
1\end{array}$ \\
\hline & くだもの & $\begin{array}{l}\text { ほぼ毎日／週に4,5 回 } \\
\text { それ以外 }\end{array}$ & $\begin{array}{r}137 \\
69 \\
\end{array}$ & $\begin{array}{l}(67) \\
(33)\end{array}$ & $\begin{array}{l}361 \\
286\end{array}$ & $\begin{array}{l}(56) \\
(44)\end{array}$ & $\begin{array}{c}1.53(1.07-2.18)^{* *} \\
1\end{array}$ & - \\
\hline & 自分の健康のために栄養や食 & とても/まあまあ気をつけている & 151 & $(74)$ & 326 & $(50)$ & $2.84(1.96-4.12)^{* * *}$ & $2.55(1.68-3.80)^{* * *}$ \\
\hline & 事について気をつけているか & それ以外 & 54 & $(26)$ & 321 & $(50)$ & 1 & 1 \\
\hline & 食事作り行動の頻度 & $\begin{array}{l}\text { いつも/時々している } \\
\text { それ以外 }\end{array}$ & $\begin{array}{r}72 \\
130\end{array}$ & $\begin{array}{l}(36) \\
(64)\end{array}$ & $\begin{array}{l}272 \\
368\end{array}$ & $\begin{array}{l}(43) \\
(58)\end{array}$ & - & - \\
\hline & 自分で食品の買い物をするか & $\begin{array}{l}\text { 週に } 1 \text { 回以上 } \\
\text { それ以外 }\end{array}$ & $\begin{array}{r}73 \\
131\end{array}$ & $\begin{array}{l}(36) \\
(64)\end{array}$ & $\begin{array}{l}251 \\
392\end{array}$ & $\begin{array}{l}(39) \\
(61)\end{array}$ & - & - \\
\hline & 朝食摂取頻度 & $\begin{array}{l}\text { ほぼ毎日 } \\
\text { それ以外 }\end{array}$ & $\begin{array}{r}181 \\
24\end{array}$ & $\begin{array}{l}(88) \\
(12)\end{array}$ & $\begin{array}{l}500 \\
146\end{array}$ & $\begin{array}{l}(77) \\
(23)\end{array}$ & $\begin{array}{c}2.12(1.30-3.47)^{* *} \\
1\end{array}$ & - \\
\hline $\begin{array}{l}\text { 行 } \\
\text { 動 }\end{array}$ & 家族との共食頻度（朝食） & $\begin{array}{l}\text { ほぼ毎日 } \\
\text { それ以外 }\end{array}$ & $\begin{array}{r}141 \\
65\end{array}$ & $\begin{array}{l}(68) \\
(32)\end{array}$ & $\begin{array}{l}313 \\
330\end{array}$ & $\begin{array}{l}(49) \\
(51)\end{array}$ & $\begin{array}{c}1.85(1.28-2.69)^{* *} \\
1\end{array}$ & - \\
\hline $\begin{array}{l}\text { 食 } \\
\text { 行 } \\
\text { 動 }\end{array}$ & 家族との共食頻度（夕食） & $\begin{array}{l}\text { ほぼ毎日 } \\
\text { それ以外 }\end{array}$ & $\begin{array}{r}167 \\
39\end{array}$ & $\begin{array}{l}(81) \\
(19)\end{array}$ & $\begin{array}{l}414 \\
229\end{array}$ & $\begin{array}{l}(64) \\
(36)\end{array}$ & $\begin{array}{c}1.91(1.21-3.03)^{* *} \\
1\end{array}$ & - \\
\hline $\begin{array}{l}\text { 健 } \\
\text { 康 }\end{array}$ & $\begin{array}{l}\text { 店内の表示やメニューのカロ } \\
\text { リー等栄養成分表示を参考に } \\
\text { しているか }\end{array}$ & $\begin{array}{l}\text { いつも/時々している } \\
\text { それ以外 }\end{array}$ & $\begin{array}{r}79 \\
117\end{array}$ & $\begin{array}{l}(40) \\
(60)\end{array}$ & $\begin{array}{l}275 \\
350\end{array}$ & $\begin{array}{l}(44) \\
(56)\end{array}$ & - & - \\
\hline 動 & $\begin{array}{l}\text { 家族や仲間と食事や料理, 栄 } \\
\text { 養のことを話すか }\end{array}$ & $\begin{array}{l}\text { いつも/時々している } \\
\text { それ以外 }\end{array}$ & $\begin{array}{r}147 \\
43\end{array}$ & $\begin{array}{l}(77) \\
(23)\end{array}$ & $\begin{array}{l}363 \\
259\end{array}$ & $\begin{array}{l}(58) \\
(42)\end{array}$ & $\begin{array}{c}2.85(1.89-4.31)^{* * *} \\
1\end{array}$ & $\begin{array}{c}2.05(1.32-3.18)^{* *} \\
1\end{array}$ \\
\hline $\begin{array}{l}\text { モ } \\
\text { デ }\end{array}$ & 健康診断受診有無 & あり & 135 & $(68)$ & 337 & $(54)$ & $1.68(1.17-2.41)^{* *}$ & $1.50(1.01-2.21)^{*}$ \\
\hline ル & & なし & 63 & $(32)$ & 285 & $(46)$ & 1 & 1 \\
\hline$\underline{2}$ & 体重計測頻度 & $\begin{array}{l}\text { 毎日／週に何回か／たまにはかって } \\
\text { いる }\end{array}$ & 112 & $(55)$ & 366 & $(57)$ & - & - \\
\hline & & はかっていない & 93 & $(45)$ & 281 & $(43)$ & & \\
\hline & サプリメント摂取 & $\begin{array}{l}\text { あり } \\
\text { なし }\end{array}$ & $\begin{array}{r}88 \\
113\end{array}$ & $\begin{array}{l}(43) \\
(56)\end{array}$ & $\begin{array}{l}243 \\
377\end{array}$ & $\begin{array}{l}(39) \\
(61)\end{array}$ & - & - \\
\hline & 契煙状況 & $\begin{array}{l}\text { 吸っている } \\
\text { 吸っていない }\end{array}$ & $\begin{array}{r}26 \\
176\end{array}$ & $\begin{array}{l}(13) \\
(87)\end{array}$ & $\begin{array}{l}116 \\
507\end{array}$ & $\begin{array}{l}(19) \\
(81)\end{array}$ & - & - \\
\hline & 排便時間規則性 & $\begin{array}{l}\text { 規則的 } \\
\text { 不規則 }\end{array}$ & $\begin{array}{r}114 \\
86\end{array}$ & $\begin{array}{l}(57) \\
(43)\end{array}$ & $\begin{array}{l}289 \\
333\end{array}$ & $\begin{array}{l}(46) \\
(54)\end{array}$ & $\begin{array}{c}1.52(1.08-2.15)^{*} \\
1\end{array}$ & - \\
\hline $\begin{array}{l}\text { 食 } \\
\text { 環 } \\
\text { 境 }\end{array}$ & $\begin{array}{l}\text { 健康づくりに家族や周囲の人 } \\
\text { は協力的か } \\
\text { 食生活について一緒に考える } \\
\text { 仲間の有無 }\end{array}$ & $\begin{array}{l}\text { いつも協力的 } \\
\text { それ以外 } \\
\text { とても/少しはいる } \\
\text { それ以外 }\end{array}$ & $\begin{array}{r}168 \\
34 \\
108 \\
90\end{array}$ & $\begin{array}{l}(83) \\
(17) \\
(55) \\
(45)\end{array}$ & $\begin{array}{l}273 \\
358 \\
216 \\
422\end{array}$ & $\begin{array}{l}(43) \\
(57) \\
(34) \\
(66)\end{array}$ & $\begin{array}{l}6.14(4.01-9.39)^{* * *} \\
1 \\
2.75(1.93-3.93)^{* * *} \\
1\end{array}$ & $\begin{array}{l}4.97(3.20-7.72)^{* * *} \\
1 \\
1.75(1.18-2.61)^{*} \\
1\end{array}$ \\
\hline $\begin{array}{l}\text { 毛} \\
\text { デ } \\
\text { ル }\end{array}$ & $\begin{array}{l}\text { よく利用する食料品店や外食 } \\
\text { 店で栄養バランスの良い食品 } \\
\text { やメニューを得ているか }\end{array}$ & $\begin{array}{l}\text { 十分／まあまあ／少し得られている } \\
\text { それ以外 }\end{array}$ & $\begin{array}{r}116 \\
77\end{array}$ & $\begin{array}{l}(60) \\
(40)\end{array}$ & $\begin{array}{l}295 \\
322\end{array}$ & $\begin{array}{l}(48) \\
(52)\end{array}$ & $\begin{array}{c}1.92(1.35-2.74)^{* * *} \\
1\end{array}$ & $\begin{array}{c}1.55(1.05-2.30)^{*} \\
1\end{array}$ \\
\hline 3 & $\begin{array}{l}\text { よく利用する食料品店や飲食 } \\
\text { 店から健康的な食事に関する } \\
\text { 情報を得ているか }\end{array}$ & $\begin{array}{l}\text { 十分／まあまあ／少し得られている } \\
\text { それ以外 }\end{array}$ & $\begin{array}{r}105 \\
89\end{array}$ & $\begin{array}{l}(54) \\
(46)\end{array}$ & $\begin{array}{l}260 \\
356\end{array}$ & $\begin{array}{l}(42) \\
(58)\end{array}$ & $\begin{array}{c}1.84(1.30-2.61)^{* *} \\
1\end{array}$ & - \\
\hline
\end{tabular}

† 未回答は欠損值として扱い, 除外した

キ 単変量解析, 多変量解析ともにステップワイズ法を用い, 共変量は性別, 年齢, 損傷部位, 受傷後経過年数, 居住形態, 社会参加の有無とした。単 変量解析は 1 つ 1 つの変数を投入し, 多変量解析はモデルごとに変数を投入した

§ OR $(95 \% \mathrm{CI})=$ オッズ比 (95\%信頼区間), それ以外の回答をオッズ比 1 とし, オッズ比が 1 より大きい場合は食生活満足度が高いことを示してい る。関連がみられなかったものはー（ハイフン）で示した

${ }^{*} p<0.05, \quad * * p<0.01, \quad * * * p<0.001$ 
ることが少ないことが推察される。しかし，治療目的の 受診と健康診断は特性が異なることから, 健康診断を受 けるといった，自身の健康についての「積極的な自己管 理」が鍵となることが示唆された。

食環境（モデル 3 ）で, 周囲の人の協力や一緒に考え る仲間といった他者との関わりや食物へのアクセスが関 連した事は，環境のうち情報ではなく人や食べ物といっ た実感できるもの，手にとってわかるもの，安心につな がるものが食生活の満足感につながったと考える。本調 查対象者は, 前報7) で在宅脊損者本人の食事づくりや食 品購買行動の頻度が低いことを報告している。脊損者で は, 生活の機能を家族や介護へルパー等に依頼している ことも多いと予測される。健康づくりに家族や周囲の人 は協力的かの変数で, いつも協力的のオッズ比が最も高 かったことからも，在宅脊損者にとって他者との関わり を通した食環境整備が重要となる。

本研究は，全脊連の登録会員への調査であるため, 在 宅疌損者全般にあてはめることはできないこと, 会員の 中でも調查に協力した者を対象としているため, 調查に 積極的であり食生活満足度が高い者に偏っている可能性 があることが限界としてあげられる。今後の課題として, 食物掑取状況, 行動, 食環境の要因間の関係を含めた, 理論枠組み全体の要因間の因果関係や相互関係を確認し, 在宅脊損者の良好な食生活につながる要因についての検 討を行っていく必要がある。

本調査は, 副菜の摂取, 栄養や食事に気をつける行動, 健康診断受診といった積極的な自己管理が在宅脊損者の 食生活満足度につながることを示唆している。また, 家 族や仲間と食事や料理, 栄養の事を話す行動や食環境の 他者との関わりとの関連は，一方向ではなく，そこにコ ミュニケーションがあることが重要であると考えられる。 このことは, 他者との関係性をみるソーシャルネット ワークやソーシャルサポートの構築も含めた食環境整備 が在宅脊損者の食生活の質を向上させる可能性を推察さ せることから, 在宅脊損者の食環境の質の向上をはかる ために食生活でどのような支援が必要であるのか, 当事 者の「なまの声」を体系的に整理し、ニーズを把握する ことができるグループインタビュー ${ }^{17)}$ などの質的調査の 実施が次の課題である。

\section{V. 結 論}

全国脊髄損傷者連合会に登録している在宅脊損者853名 （有効回答率 $31 \%$ ）を対象に, 食生活満足度と関係する食 物拱取状況, 行動 (食行動- 健康行動), 食環境の要因に
ついての検討をおこなった。関倸がみられた変数を要約 すると, 食物摂取状況は「副菜」, 行動（食行動・健康行 動）は「積極的な自己管理」，「家族や仲間との会話」，食 環境は「他者との関わり」，「食物へのアクセス」であっ た。

\section{謝 辞}

本調查に御協力いただきました社団法人全国脊䯣損傷 者連合会の会員の皆さまに深謝いたします。本研究は平 成23年度科学研究費補助金 (基盤 C, 一般),「在宅の車 椅子利用者の生活の質と健康を保つための栄養・食生活 支援に関する研究」の一環として実施した。

\section{利益相反}

利益相反に相当する事項はない。

\section{文献}

1）健康づくりのための食環境整備に関する検討会：健康 づくりのための食環境整備の必要性, 健康づくりのため の食環境整備に関する検討会報告書, pp. 9-12（2004） 厚生労働省, 東京

2）厚生労働省：健康日本21（第 2 次）の推進に関する参考 資料，http://www.mhlw.go.jp/bunya/kenkou/kenkounippon 21.html, （2012年12月 1 日）

3）厚生労働省 : 栄養 - 食生活, 健康日本21, http://www1. mhlw.go.jp/topics/kenko21_11/blf.html，（2012年12月 1 日)

4) Green, L.W., Kreuter, M.W.: Health program planning: An educational and ecological approach 4th ed./神馬征峰 訳，実践ヘルスプロモーション PRECEDE-PROCEED モ デルによる企画と評価，pp. 8-25（2005）医学書院，東京

5) Stotts, J.L., Lohse, B.: Reliability of the ecSatter Inventory as a tool to measure eating competence, J. Nutr. Educ. Behav., 39, 167-170 (2007)

6）武見ゆかり：行動科学に基づく栄養教育と支援的環境 づくりによる地域住民の望ましい食習慣形成に関する研 究, 平成14年度厚生労働科学研究費補助金健康科学総合 研究事業「行動科学に基づく栄養教育と支援的環境づく りによる地域住民の望ましい食習慣形成に関する研究」 報告書, （武見ゆかり）, pp. 1-14（2003）厚生労働省, 東京

7）秦希久子, 角田伸代，稲山貴代：在宅脊髄損傷者の食 生活の包括的特性ならびに性・年齢区分・損傷部位によ る差異についての検討, 栄養学雑誌, 70, 346-361 (2012)

8）健康 - 栄養情報研究会編：国民健康 - 栄養の現状一平 成18年厚生労働省国民健康・栄養調查報告より一, pp. 93-98（2009）第一出版, 東京

9）佐久間肇，樋口幸治：平成17年度総括報告書，厚生労 働科学研究費補助金障害保健福祉総合研究事業「脊髄損 傷者の生活習慣病・二次的障害予防のための適切な運動 処方・生活指導に関する研究」平成17～19年度総合研究 
報告書，（樋口幸治），pp．5-25（2008）厚生労働省，東 京

10) Liou, T.H., Pi-Sunyer, F.X., Laferrere, B.: Physical disability and obesity, Nutr. Rev., 63, 321-331 (2005)

11) Tate, D.G., Riley, B.B., Perna, R., et al.: Quality of life issues among women with physical disabilities or breast cancer, Arch. Phys. Med. Rehabil., 78, S18-25（1997）

12) Norman, G.J., Kolodziejczyk, J.K., Adams, M.A., et al.: Fruit and vegetable intake and eating behaviors mediate the effect of a randomized text-message based weight loss program, Prev. Med., 56, 3-7 (2013)

13) Mirmiran, P., Noori, N., Zavareh, M.B., et al.: Fruit and vegetable consumption and risk factors for cardiovascular disease, Metabolism, 58, 460-468 (2009)

14) Carter, P., Gray, L.J., Troughton, J., et al.: Fruit and vegetable intake and incidence of type 2 diabetes mellitus: systematic review and meta-analysis, $B M J, 341$, c4229 (2010)

15）佐久間肇：頸髄損傷者の社会参加一自己管理，頚髄損 傷のリハビリテーション改訂第 2 版，（二瓶隆一，木村哲 彦，牛山武久，他編）, pp. 248-252（2006）協同医書出 版社，東京

16）厚生労働省：保険者による健診・保健指導等に関する 検討会（第 9 回）, http://www.mhlw.go.jp/stf/shingi/ 2r9852000002d8ft.html，（2012年12月 7 日）

17）安梅勅江：グループインタビュー法とは，ヒューマ ン・サービスにおけるグループインタビュー法一科学的 根拠に基づく質的研究法の展開, p. 3 (2001) 医歯薬出 版, 東京

（受付：平成24年12月27日，受理：平成25年 4 月 22 日） 


\title{
Associations between Dietary Satisfaction and Food Intake, Behavioral, and Dietary Environmental Factors in Community-dwelling Individuals with Spinal Cord Injury
}

\author{
Kikuko Hata*1 and Takayo Inayama*1 \\ ${ }^{* 1}$ Graduate School of Human Health Sciences, Tokyo Metropolitan University
}

\begin{abstract}
Objective: We determined the correlation between dietary satisfaction and lifestyle (food intake and behavior) and environmental (dietary environment) factors in community-dwelling individuals with spinal cord injuries (SCIs).

Methods: In September 2011, we posted a questionnaire to 2,731 registered members of Spinal Injuries Japan. The questionnaire included items on dietary satisfaction, food intake, behavior, and dietary environment. We received responses from 1,000 people, but excluded responses in which crucial data such as sex, age, injured body part, and type of disability were missing. Finally, responses from 853 people were analyzed. The correlations between dietary satisfaction and food intake, behavior, and dietary environment were determined by binomial logistic regression analysis.

Results: A significant association was found between dietary satisfaction and vegetable and potato intake (food intake factors). Dietary satisfaction significantly correlated with self-health care with respect to nutrition and diet, mealtime conversation with family, and medical examination (behavioral factors). Dietary satisfaction significantly correlated with family/neighbors cooperation for health promotion, learning diet/nutrition with a friend, and eating healthy outside the home (dietary environmental factors).

Conclusions: The food intake, behavioral, and dietary environment factors associated with dietary satisfaction in community-dwelling individuals with SCIs were vegetables, self-health management, communication with family and friends, peer support, and food access.
\end{abstract}

Jpn. J. Nutr. Diet., 71 (3) 138 144 (2013)

Key words: spinal cord injury, dietary satisfaction, food intake, behavior, dietary environment 